\title{
Inhibition of CD200R1 expression by C/EBP beta in reactive microglial cells
}

\author{
Guido Dentesano ${ }^{1}$, Marco Straccia ${ }^{1,2}$, Aroa Ejarque-Ortiz ${ }^{1}$, Josep M Tusell ${ }^{1}$, Joan Serratosa ${ }^{1}$, Josep Saura ${ }^{2}$
} and Carme Solà ${ }^{1 *}$

\begin{abstract}
Background: In physiological conditions, it is postulated that neurons control microglial reactivity through a series of inhibitory mechanisms, involving either cell contact-dependent, soluble-factor-dependent or neurotransmitter-associated pathways. In the current study, we focus on CD200R1, a microglial receptor involved in one of these cell contact-dependent mechanisms. CD200R1 activation by its ligand, CD200 (mainly expressed by neurons in the central nervous system),is postulated to inhibit the pro-inflammatory phenotype of microglial cells, while alterations in CD200-CD200R1 signalling potentiate this phenotype. Little is known about the regulation of CD200R1 expression in microglia or possible alterations in the presence of pro-inflammatory stimuli.

Methods: Murine primary microglial cultures, mixed glial cultures from wild-type and CCAAT/enhancer binding protein $\beta$ (C/EBP $\beta$ )-deficient mice, and the BV2 murine cell line overexpressing C/EBP $\beta$ were used to study the involvement of C/EBP $\beta$ transcription factor in the regulation of CD200R1 expression in response to a proinflammatory stimulus (lipopolysaccharide (LPS)). Binding of C/EBP $\beta$ to the CD200R1 promoter was determined by quantitative chromatin immunoprecipitation (qChIP). The involvement of histone deacetylase 1 in the control of CD200R1 expression by C/EBP $\beta$ was also determined by co-immunoprecipitation and qChIP.

Results: LPS treatment induced a decrease in CD200R1 mRNA and protein expression in microglial cells, an effect that was not observed in the absence of C/EBP $\beta$. C/EBP $\beta$ overexpression in BV2 cells resulted in a decrease in basal CD200R1 mRNA and protein expression. In addition, C/EBP $\beta$ binding to the CD200R1 promoter was observed in LPS-treated but not in control glial cells, and also in control BV2 cells overexpressing C/EBP $\beta$. Finally, we observed that histone deacetylase 1 co-immunoprecipitated with C/EBP $\beta$ and showed binding to a C/EBP $\beta$ consensus sequence of the CD200R1 promoter in LPS-treated glial cells. Moreover, histone deacetylase 1 inhibitors reversed the decrease in CD200R1 expression induced by LPS treatment.
\end{abstract}

Conclusions: CD200R1 expression decreases in microglial cells in the presence of a pro-inflammatory stimulus, an effect that is regulated, at least in part, by C/EBP $\beta$. Histone deacetylase 1 may mediate C/EBP $\beta$ inhibition of CD200R1 expression, through a direct effect on C/EBP $\beta$ transcriptional activity and/or on chromatin structure.

Keywords: Neuroinflammation, Reactive microglia, CD200R1, C/EBPß, Neuron-microglia communication, In vitro

\footnotetext{
* Correspondence: carme.sola@iibb.csic.es

'Department of Cerebral Ischemia and Neurodegeneration, Institut d'Investigacions Biomèdiques de Barcelona-Consejo Superior de Investigaciones Científicas (CSIC), Institut d'Investigacions Biomèdiques August Pi i Sunyer (IDIBAPS), C/ Rosselló 161, 6th Floor, Barcelona E-08036, Spain

Full list of author information is available at the end of the article
}

\section{Ciomed Central}

(c) 2012 Dentesano et al.; licensee BioMed Central Ltd. This is an Open Access article distributed under the terms of the Creative Commons Attribution License (http://creativecommons.org/licenses/by/2.0), which permits unrestricted use, distribution, and reproduction in any medium, provided the original work is properly cited. 


\section{Background}

In the presence of neuronal damage, microglial cells acquire reactive phenotypes characterized by both morphological and functional changes [1,2]. Microglial activation is a beneficial response, aimed at re-establishing brain homeostasis and avoiding or minimizing neuronal damage. However, reactive microglial cells produce several factors (pro-inflammatory cytokines, reactive oxygen and nitrogen species) that are typical of an inflammatory response, with potential neurotoxic effects. Consequently, the progression and resolution of microglial activation need to be tightly controlled to avoid the negative secondary effects of excessive or chronic microglial reactivity [3].

In the normal brain, it has been postulated that microglial reactivity is maintained under control by a series of inhibitory mechanisms, in which signals arising from neuronal cells are thought to play an important role (reviewed in [4]). Alterations in these inhibitory signals can result in microglial activation. In the presence of brain tissue injury, microglial cells become activated with a pro-inflammatory phenotype, suggesting that the inhibitory mechanisms have been overcome. In the present work, we focused on the study of one of these inhibitory mechanisms: the CD200-CD200R1 ligandreceptor system.

In the central nervous system (CNS), microglial cells express CD200R1 and CD200 is constitutively expressed mainly by neurons. Results from studies using CD200deficient mice suggest that this protein plays an important role in the inhibition of the microglial proinflammatory phenotype in the normal brain [5-8]. Results from in vitro studies also suggest a role for CD200 in the control of microglial activation $[9,10]$. CD200 expression is decreased in the human brain of patients with multiple sclerosis [11,12], and both CD200 and CD200R1 expression are decreased in the brain of Alzheimer's disease patients [13]. These observations suggest that the CD200-CD200R1 inhibitory pathway is altered in neurodegenerative disorders affecting the human brain, in which glial activation/neuroinflammation has been suggested to play a role in progression of the neurodegeneration.

Little is known about the molecular mechanisms involved in the regulation of CD200 and CD200R1 expression in physiological and pathological conditions or on the mechanisms involved in the control of the microglial pro-inflammatory response in the presence of CD200R1 stimulation. In terms of CD200, Rosenblum et al. [14] described the presence of functional DNA binding sites for tumor suppressor protein $\mathrm{p} 53$, a critical regulator of the apoptotic program, in the promoters of the human and mouse CD200 gene and suggested a role for CD200 in the regulation of apoptosis. Gorczynski's group detected a C/EBP $\beta$ binding site in the promoter of the human CD200 gene that is required for the constitutive expression of CD200 [15]. The same group also reported that STAT1 $\alpha$, NF- $-\mathrm{B}$ p 65 and IRF-1 play a role in the regulation of $\mathrm{CD} 200$ inducible expression in human T-cell lines [16]. Lyons et al. [9] showed that the anti-inflammatory cytokine IL-4 induced an increase in CD200 expression in rat neurons both in vivo and in vitro. In contrast, molecular mechanisms controlling the expression of CD200R1 have yet to be identified.

The CCAAT/enhancer binding protein $\beta(\mathrm{C} / \mathrm{EBP} \beta)$ transcription factor is known to play a role in the control of the expression of genes encoding pro-inflammatory factors in reactive glial cells $[17,18]$. However, little is known about its role in the regulation of genes encoding anti-inflammatory factors. The objective of the present work was to study whether C/EBP $\beta$ plays a role in the regulation of CD200R1 expression in microglial cells. Using glial cultures from wild-type and C/EBP $\beta$-deficient mice and BV2 cells (microglial cell line) overexpressing $C / E B P \beta$, we show that this transcription factor downregulates the expression of CD200R1 in reactive microglial cells, an effect that is mediated, at least in part, by histone deacetylase (HDAC) 1.

\section{Methods}

\section{Animals}

A colony of C/EBP $\beta+/-$ mice [19] on a C57BL/6-129 S6/ SvEv background was used to obtain $\mathrm{C} / \mathrm{EBP} \beta+/+$ and $\mathrm{C} /$ EBP $\beta-/$ - mixed glial cultures as previously described by Straccia et al. [18]. Experiments were carried out in accordance with the Guidelines of the European Union Council (86/609/EU) and following the Spanish regulations (BOE 67/8509-12, 1988) for the use of laboratory animals, and were approved by the Ethics and Scientific Committees of Barcelona University and the Hospital Clínic de Barcelona.

\section{Cell cultures}

Mixed glial cultures were obtained from pools of cerebral cortices of two- to four-day-old C57BL/6 wild-type mice as described by Gresa-Arribas et al. [20]. In the experiments with $\mathrm{C} / \mathrm{EBP} \beta$-deficient mice, $\mathrm{C} / \mathrm{EBP} \beta+/+$ and $C / E B P \beta-/-$ mixed glial cultures were obtained from single 19-day-old embryos from $\mathrm{C} / \mathrm{EBP} \beta+/$ - progenitors as described by Straccia et al. [18], due to the infertility of $\mathrm{C} / \mathrm{EBP} \beta-/$ - females and a perinatal death rate of approximately $50 \%$ for $C / E B P \beta-/$ - neonates. The culture medium consisted of Dulbecco's modified Eagle medium (DMEM)/F-12 nutrient mixture (Invitrogen, Carlsbad, CA, USA) supplemented with $10 \%$ fetal bovine serum (FBS, Invitrogen), $0.1 \%$ penicillin-streptomycin (Invitrogen), and $0.5 \mathrm{mg} / \mathrm{mL}$ amphotericin $B$ (Fungizone ${ }^{\circledR}$, Invitrogen). Cells were maintained at $37^{\circ} \mathrm{C}$ in a $5 \% \mathrm{CO}_{2}$ 
humidified atmosphere. Medium was replaced every five to sevendays.

Microglial cultures were prepared from 19 to 21 days in vitro (DIV) mixed glial cultures using the mild trypsinization method as previously described by our group [21]. Briefly, the cultures were treated for 30 minutes with $0.06 \%$ trypsin in the presence of $0.25 \mathrm{mM}$ ethylenediamine tetraacetic acid (EDTA) and $0.5 \mathrm{mM} \mathrm{Ca}^{2+}$. This resulted in the detachment of an intact layer of cells containing virtually all the astrocytes, leaving a population of firmly attached cells identified as $>98 \%$ microglia. The microglial cultures were used 24 hours after isolation. Flow cytometry studies, qRT-PCR assays, quantitative chromatin immunoprecipitation (qChIP) and coimmunoprecipitation experiments were performed using primary mixed glial cultures due to the limited amount of primary microglial cells usually obtained.

Astroglia-enriched cultures were obtained as described by Saura et al. [22].

The mouse microglial cell line BV2 (generated from primary mouse microglia transfected with a v-raf/v-myc oncogene, Blasi et al. [23]) was kindly provided by Dr. Elisabetta Blasi (Dip. Scienze Igienistiche, Microbiologiche e Biostatistiche, Modena, Italy). Cells were cultured in Roswell Park Memorial Institute (RPMI)-1640 medium (Invitrogen), supplemented with $0.1 \%$ penicillin-streptomycin (Invitrogen) and 10\% heat-inactivated FBS. Cells were maintained at $37^{\circ} \mathrm{C}$ in a $5 \% \mathrm{CO}_{2}$ humidified atmosphere. Stable clones overexpressing the C/EBP $\beta$ LAP isoform were obtained. Briefly, BV2 cells were transfected with 1 $\mu \mathrm{g}$ pCDNA (empty vector) or pCDNA-LAP expression plasmids (Dr. Steven Smale, UCLA, USA) using Lipofectamine 2000 (Invitrogen). Positive clones were selected with Zeocin $^{\text {Th }}(150 \mu \mathrm{g} / \mathrm{mL})$ (Invitrogen) associated resistance. Cells were seeded at a density of $5 \times 10^{4}$ cells $/ \mathrm{mL}\left(1.6 \times 10^{4}\right.$ cells $/ \mathrm{cm}^{2}$ ) for immunocytochemistry and at $10^{5}$ cells $/ \mathrm{mL}$ $\left(2.4 \times 10^{6}\right.$ cells $\left./ \mathrm{cm}^{2}\right)$ for protein and RNA extraction. One day after seeding, the culture medium was replaced with fresh RPMI medium, and the cells were used one day later.

\section{Treatments}

Cells were exposed to $100 \mathrm{ng} / \mathrm{mL}$ LPS from Escherichia coli (026:B6, Sigma-Aldrich, St. Louis, MO, USA) for different lengths of time.

The HDAC inhibitors suberoylanilide hydroxamic acid (SAHA) and MS-275 (Cayman Chemicals, Ann Arbor, MI, USA) were used at $100 \mathrm{nM}, 500 \mathrm{nM}, 1 \mu \mathrm{M}$ and $10 \mu \mathrm{M}$. They were added to the cultures one hour before LPS treatment.

\section{Immunocytochemistry}

Cultured cells were fixed with $4 \%$ paraformaldehyde in $0.1 \mathrm{M}$ phosphate buffer ( $\mathrm{pH}$ 7.4) for 20 minutes at room temperature. Non-specific staining was blocked by incubating cells with 10\% normal donkey serum (Vector, Peterborough, UK) in PBS containing 1\% BSA for 20 minutes at room temperature. Cells were then incubated overnight at $4{ }^{\circ} \mathrm{C}$ with polyclonal goat antiCD200R1 (1:50, R\&D, Abingdon, UK), alone or in combination (mixed glial cultures) with monoclonal rat anti-CD11b (1:200, Serotec, Oxford, UK) or polyclonal rabbit anti-GFAP (1:1000, DAKO, Glostrub, DK) primary antibodies. After rinsing in PBS, cells were incubated for one hour at room temperature with donkey anti-goat ALEXA 488 (1:500) or ALEXA 594 (1:500), alone or in combination with donkey anti-rat ALEXA 594 (1:500) or donkey anti-rabbit ALEXA 546 (1:1000) secondary antibodies (Molecular Probes, Eugene, OR, USA). In the case of mixed glial cultures, cells were permeated with $0.3 \%$ Triton X-100 in PBS containing 1\% BSA and $10 \%$ normal donkey serum for 20 minutes at room temperature following fixation. Cell nuclei were stained with Hoechst 33258 (Sigma). Microscopy images were obtained with an Olympus IX70 microscope (Olympus, Okoya, Japan) and a digital camera (CC-12, Olympus Soft Imaging Solutions GmbH, Hamburg, Germany).

\section{Isolation of total and nuclear proteins}

Total protein extracts were obtained from mixed glial cultures and BV2 cells. One well on a six-well plate was used for each experimental condition. After a cold PBS wash, cells were scraped off and recovered in $100 \mu \mathrm{L}$ of radioimmunoprecipitation assay (RIPA) buffer per well (1\% Igepal CA-630, $5 \mathrm{mg} / \mathrm{mL}$ sodium deoxycholate, $1 \mathrm{mg} / \mathrm{mL}$ SDS, protease inhibitor cocktail Complete ${ }^{\circledR}$ Roche Diagnostics, Mannheim, Germany- in PBS). Samples were sonicated, centrifuged for five minutes at $10,400 \mathrm{~g}$ and stored at $-20^{\circ} \mathrm{C}$. The amount of protein was determined using the Lowry assay (Total protein kit micro-Lowry, Sigma-Aldrich).

\section{Western blot}

Total protein extracts $(50 \mu \mathrm{g})$ or immunoprecipitated samples were denatured (120 mM Tris $\mathrm{HCl} \mathrm{pH} 6.8,10 \%$ glycerol, 3\% SDS, $20 \mathrm{mM}$ dithiothreitol (DTT), and 0.4\% bromophenol blue, $100^{\circ} \mathrm{C}$ for five minutes) and subjected to SDS-PAGE on a $10 \%$ polyacrylamide minigel, together with a molecular weight marker (Fullrange Rainbow Molecular Weight Marker, GE Healthcare, Little Chalfont, UK), and transferred to a polyvinylidene fluoride (PVDF) membrane (Millipore, Bedford, MA, USA) for 90 minutes at $1 \mathrm{~mA} / \mathrm{cm}^{2}$. The detection of the proteins of interest was performed as described by Gresa-Arribas et al. [20]. Monoclonal mouse anti-C /EBP $\beta$ (1:500, Abcam, Cambridge, UK) and monoclonal mouse anti- $\beta$-actin (1:50000, Sigma-Aldrich) were used as primary antibodies. Horseradish peroxidase-labelled goat anti-mouse was used as the secondary antibody 
(1:5000, Santa Cruz Biotechnology, Temecula, CA, USA). The signal was developed with ECL-Plus (GE) and images were obtained using a VersaDoc System (Bio-Rad Laboratories, Hercules, CA, USA). The pixel intensities of the immunoreactive bands were quantified using the \% adjusted volume feature of Quantity One 5.4.1 software (Bio-Rad Laboratories). Data are expressed as the ratio between the intensity of the $\mathrm{C} /$ EBP $\beta$ band and the loading control protein band $(\beta-$ actin).

\section{Quantitative real-time PCR}

CD200R1 and C/EBP $\beta$ mRNA expression was determined in primary glial cultures and BV2 cells six hours after treatments. For isolation of total RNA, one well from six-well culture plates was used per experimental condition, with the exception of primary microglial cultures, where one $75 \mathrm{~cm}^{2}$ flask was considered. Total RNA was isolated using a High Pure RNA Isolation Kit (Roche Diagnostics) and $1.5 \mu \mathrm{g}$ of RNA for each condition was reverse transcribed with random primers using Transcriptor Reverse Transcriptase (Roche Diagnostics). Three nanograms of cDNA were used to perform quantitative real-time PCR. The following primers (Integrated DNA Technology, IDT) were used: 5'-AGGAGGATGAAATGCAGCCTTA-3' (Forward) and 5'-TGCCTCCACCTTAGTCACAGTATC-3' (Reverse) to amplify mouse CD200R1 mRNA; 5'-AAGCTGAGCGACGAGTACAAGA-3' (Forward) and 5'-GTCAGCTCCAGCACCTTGTG-3' (Reverse) for mouse C/EBP $\beta$. For the normalization of cycle threshold $(\mathrm{Ct})$ values to an endogenous control, the following primers were used: 5'-CAACGAGCGGTTCCGATG-3' (Forward) and 5'GCCACAGGATTCCATACCCA-3' (Reverse) for mouse $\beta$-actin mRNA and 5'-GTAACCCGTTGAACCCCATT-3' (Forward) and CCATCCAATCGGTAGTAGCG (Reverse) for mouse Rn18s mRNA; $\beta$-actin and Rn18s mRNA levels were not altered by cell treatment. Real-time PCR was carried out using the IQ SYBR Green SuperMix (Bio-Rad Laboratories) in $15 \mu \mathrm{L}$ of final volume using an iCycler MyIQ apparatus (Bio-Rad Laboratories). Samples were run for 50 cycles $\left(95^{\circ} \mathrm{C}\right.$ for 15 seconds, $60^{\circ} \mathrm{C}$ for 30 seconds, and $72^{\circ} \mathrm{C}$ for 15 seconds). Relative gene expression values were calculated using the comparative Ct or $\Delta \Delta$ Ct method [24] and iQ5 2.0 software (Bio-Rad Laboratories). Ct values were corrected according to the amplification efficiency of the respective primer pair which was estimated from standard curves generated by dilution of a cDNA pool.

\section{Flow cytometry}

CD200R1 protein expression was analyzed in control and LPS-treated (24 hours) mixed glial cultures and BV2 cells. For each experimental condition, $5 \times 10^{5}$ cells were collected and labelled with $10 \mu \mathrm{g} / \mathrm{mL}$ of polyclonal goat anti-CD200R1 (R\&D, Abingdon, UK) or goat immunoglobulin G (IgG) (isotype control) in PBS for 20 minutes. Cells were washed once in PBS and incubated with $1 \mu \mathrm{g} / \mathrm{mL}$ of donkey anti-goat ALEXA 488 secondary antibody (Molecular Probes) for 20 minutes. Cell viability was evaluated by incubation with $10 \mu \mathrm{g} / \mathrm{mL}$ propidium iodide (Molecular Probes). CD200R1 expression was analyzed with gating on live cells, using the $\mathrm{BD}$ FACSCalibur $^{\mathrm{ru}}$ platform (BD, Franklin Lakes, NJ, USA).

\section{Quantitative chromatin immunoprecipitation (qChIP)}

qChIP was performed as described by Straccia et al. [18] with some modifications. Briefly, control and LPStreated (4 hours) primary mixed glial cultures or BV2 cells were cross-linked with formaldehyde $(1 \% \mathrm{vol} / \mathrm{vol}$ final concentration) and processed for chromatin extraction. Chromatin shearing resulted in fragments of $500 \mathrm{bp}$. An aliquot of chromatin sheared from each sample was separated as a loading control for the experiment (input). The rest of the sample was processed for chromatin immunoprecipitation (ChIP) using Dynabeads $^{\circledR}$ protein $\mathrm{A}$ (Invitrogen) and $2 \mu \mathrm{g}$ of polyclonal rabbit anti-C/EBP $\beta$ antibody (Santa Cruz Biotechnology) or rabbit IgG (Santa Cruz Biotechnology) as the negative control. DNA was isolated after the elimination of the protein from the immunoprecipitated samples. Input and ChIP samples were analyzed using real-time PCR and SYBR green (Bio-Rad). Three microliters of input DNA (diluted 1/50) and ChIP samples were amplified in triplicate in 96-well plates using the MyIQ Bio-Rad Real Time Detection System, as described in the section on quantitative real-time PCR. The C/EBP $\beta$ binding site in the IL-10 promoter was used as a positive control (Liu et al., 2003). Match-1.0 (public version, BioBase) and MatInspector (Genomatix) were used to identify $\mathrm{C} /$ $\mathrm{EBP} \beta$ consensus sequences in the $5,000 \mathrm{bp}$ region upstream from the ATG translation start site of the CD200R1 gene. The sequences for each amplified locus and the primers used are shown in Table 1. Samples were run for 45 cycles $\left(95^{\circ} \mathrm{C}\right.$ for 30 seconds, $62^{\circ} \mathrm{C}$ for one minute, and $72^{\circ} \mathrm{C}$ for 30 seconds). For details regarding data analysis see the section on quantitative real-time PCR.

\section{Co-immunoprecipitation}

Fifty microliters of Dynabeads ${ }^{\circledR}$ protein A (Invitrogen, No.100.01D) were washed three times in PBS with $0.02 \%$ Tween-20 and incubated for two hours at $4^{\circ} \mathrm{C}$ with $4 \mu \mathrm{g}$ of polyclonal rabbit anti-C/EBP $\beta$ (Santa Cruz Biotechnology), or with $4 \mu \mathrm{g}$ of rabbit IgG (Santa Cruz Biotechnology) as negative control. Two hundred micrograms of protein obtained from chromatin extracts from control and LPStreated (six hours) mixed glial cultures, as described above in the qChIP protocol, were incubated overnight with the 
Table 1 C/EBP $\beta$ putative binding sites in CD200R1 gene promoter and primers used in quantitative ChIP assay

\begin{tabular}{lllll}
\hline Box & Genomic localization with respect to ATG & C/EBP $\beta$ consensus sequence & Primers \\
\hline $\mathbf{1}$ & -4028 & -4014 & tgATTCacaaat & Fwd: 5'-CATTCCTGCTTCTGTCATGTG-3' \\
$\mathbf{2}$ & -3723 & -3708 & gtctttgGAAATtt & Rev: 5'- GCCCTTACGCTTAACATCCA-3' \\
$\mathbf{3}$ & -2793 & -2779 & tgcttgaGCAATtt & Fwd: 5'-CTTGGGAAAGTTGGGTTGTG-3' \\
$\mathbf{4}$ & -2546 & ggcttggGAAAGtt & Rev: 5'-TCCACACCATGGAGTTCATAA-3' \\
$\mathbf{5}$ & -1369 & atgtttgGCAAGag & Fwd: 5'-TGAGAGGTGGAGGAGGGTAA-3' \\
& & -2529 & & Rev: 5'-TCCTACCCCTGAGCAAAATG-3' \\
$\mathbf{6}$ & -450 & tggttagGAAATtt & Fwd: 5'-TCTCACCATGGCATTTCAA-3' \\
& & & Rev: 5'-ATGCCCAAGACAGATGGATG-3' \\
\hline
\end{tabular}

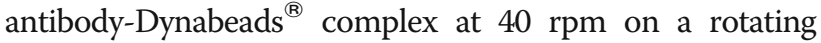
wheel at $4^{\circ} \mathrm{C}$. The immuno complexes were pelleted using a magnetic rack and washed three times with PBS. Beads were removed from the samples by boiling in sample buffer (120 mM Tris $\mathrm{HCl}$ pH 6.8, 10\% glycerol, 3\% SDS, $20 \mathrm{mM}$ DTT, and $0.4 \%$ bromophenol blue) for five minutes. Input (1/5 dilution) and immunoprecipitated samples were subjected to SDS-PAGE on a $10 \%$ polyacrylamide minigel. Western blot analysis was conducted as described above using monoclonal anti-HDAC1 antibody (1:2500, clone $2 \mathrm{E} 10$, Millipore) and monoclonal mouse anti-C/EBP $\beta$ antibody (1:500, Abcam). Samples immunoprecipitated with isotype-Dynabeads ${ }^{\circledR}$ or incubated with unlabeled beads were used as negative controls to demonstrate the specificity of the signal obtained.

\section{Data presentation and statistical analysis}

The results are presented as the means + standard error of the mean (SEM). Statistical analyses were performed using one-way or two-way analysis of variance (ANOVA) followed by the Bonferroni post-test when three or more experimental groups were compared. Student's $t$-test was used to compare two experimental groups. Values of $\mathrm{P}<0.05$ were considered statistically significant.

\section{Results}

CD200R1 expression in microglial cells decreases in response to the pro-inflammatory stimulus LPS

CD200R1 expression was determined by immunocytochemistry in primary microglial cells in basal conditions and 12, 24 and 48 hours after LPS treatment. CD200R1 immunolabeling was observed in control primary microglial cells, defining the shape of the cells (Figure 1A). No differences in immunolabeling were observed between control and treated microglia 12 hours after LPS (Figure 1B); however, a marked decrease in labeling was observed 24 hours post-treatment (Figure 1C), and was still present at 48 hours (Figure 1D). CD200R1 immunocytochemistry was also evaluated in control and LPS-treated primary mixed glial cultures, composed of astrocytes and microglia.
Basal expression of CD200R1 was observed in control cultures (Figure 2A, C and D). CD200R1 immunolabeling in the primary mixed glial cultures was localized in microglial (Figure 2C, E, G and I) but not in astroglial cells (Figure 2D, F, H and J). LPS treatment resulted in a decrease in CD200R1 labeling in the microglial cells (Figure 2B). These results were confirmed at the level of mRNA expression (Figure 3A). Basal expression of CD200R1 mRNA was observed in control primary microglial cultures and a decrease was observed in LPS-treated cultures. No significant CD200R1 mRNA expression was detected in astroglia-enriched cultures. We also detected a decrease in CD200R1 protein expression in LPS-treated primary mixed glial cultures via flow cytometry (Figure 3B).

The absence of C/EBP $\beta$ prevents the inhibition of CD200R1 expression in response to LPS in microglial cells To test whether C/EBP $\beta$ plays a role in the transcriptional regulation of CD200R1, we analyzed CD200R1

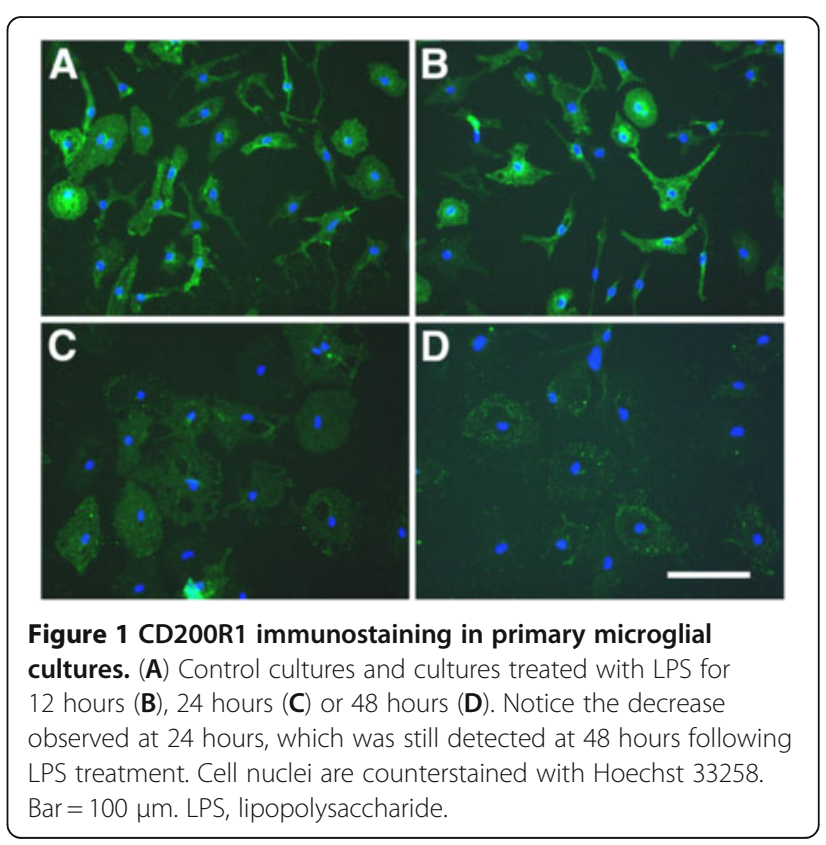



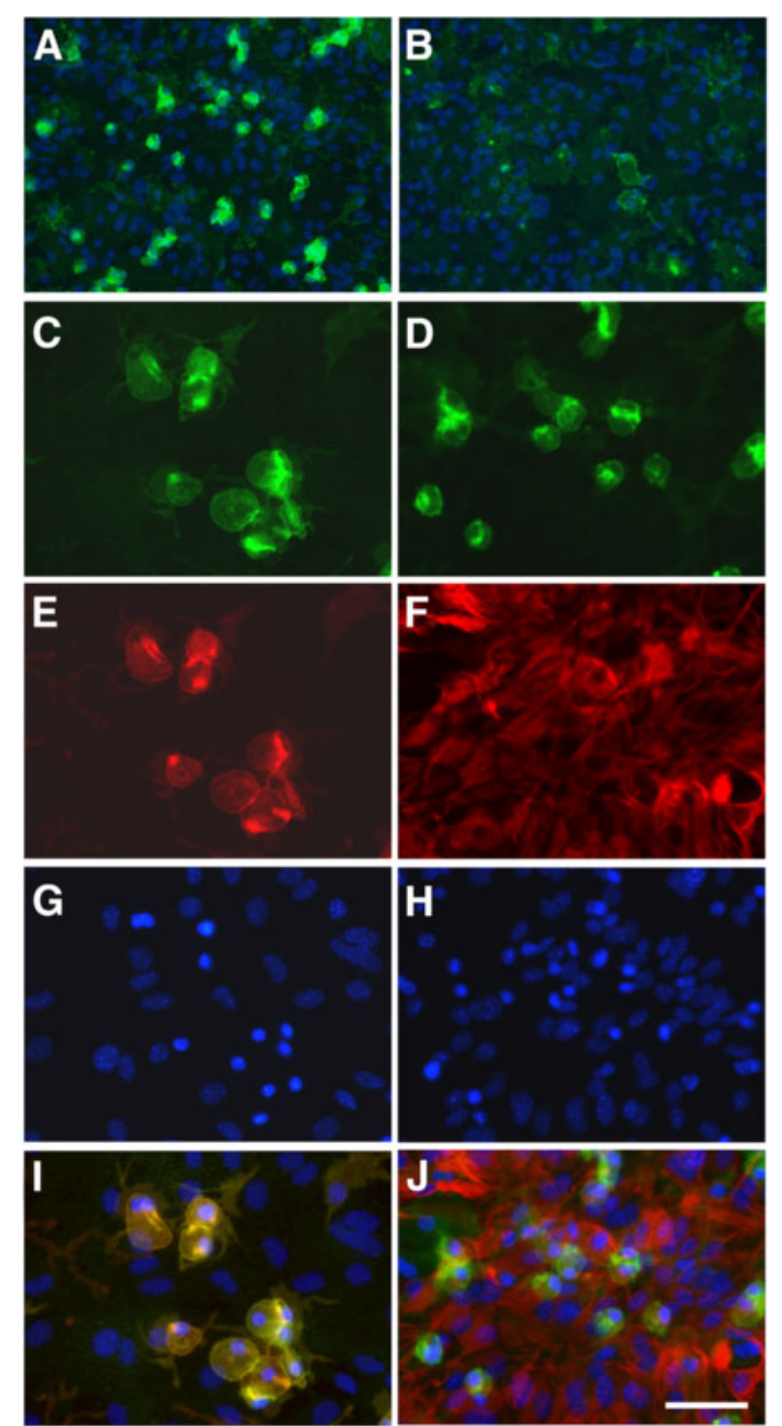

Figure 2 CD200R1 immunostaining in primary mixed glial cultures. CD200R1 immunostaining in control primary mixed glial cultures (A) and 24 hours after LPS treatment (B). The signal was reduced in LPS-treated cultures. CD200R1 immunostaining (C and D) is localized in anti-CD11b labelled cells (microglia) (E) but not in anti-GFAP labelled cells (astrocytes) (F). $\mathbf{G}$ and $\mathbf{H}$ show Hoechst 33258 staining in the corresponding fields. I and $\mathbf{J}$ show merge images. Bar $=100 \mu \mathrm{m}$ in A-B and $50 \mu \mathrm{m}$ in C-J. LPS, lipopolysaccharide.

mRNA expression in control and LPS-treated primary mixed glial cultures of wild-type and C/EBP $\beta$-deficient mice using quantitative real-time PCR. We first confirmed that $\mathrm{C} / \mathrm{EBP} \beta$ protein expression was basally detected in wild-type mixed glial cultures and increased after LPS treatment, but was absent in C/EBP $\beta$-deficient cultures (Figure 4A). CD200R1 mRNA expression was significantly lower in wild-type cultures six hours after LPS treatment (Figure 4B). However, this decrease was

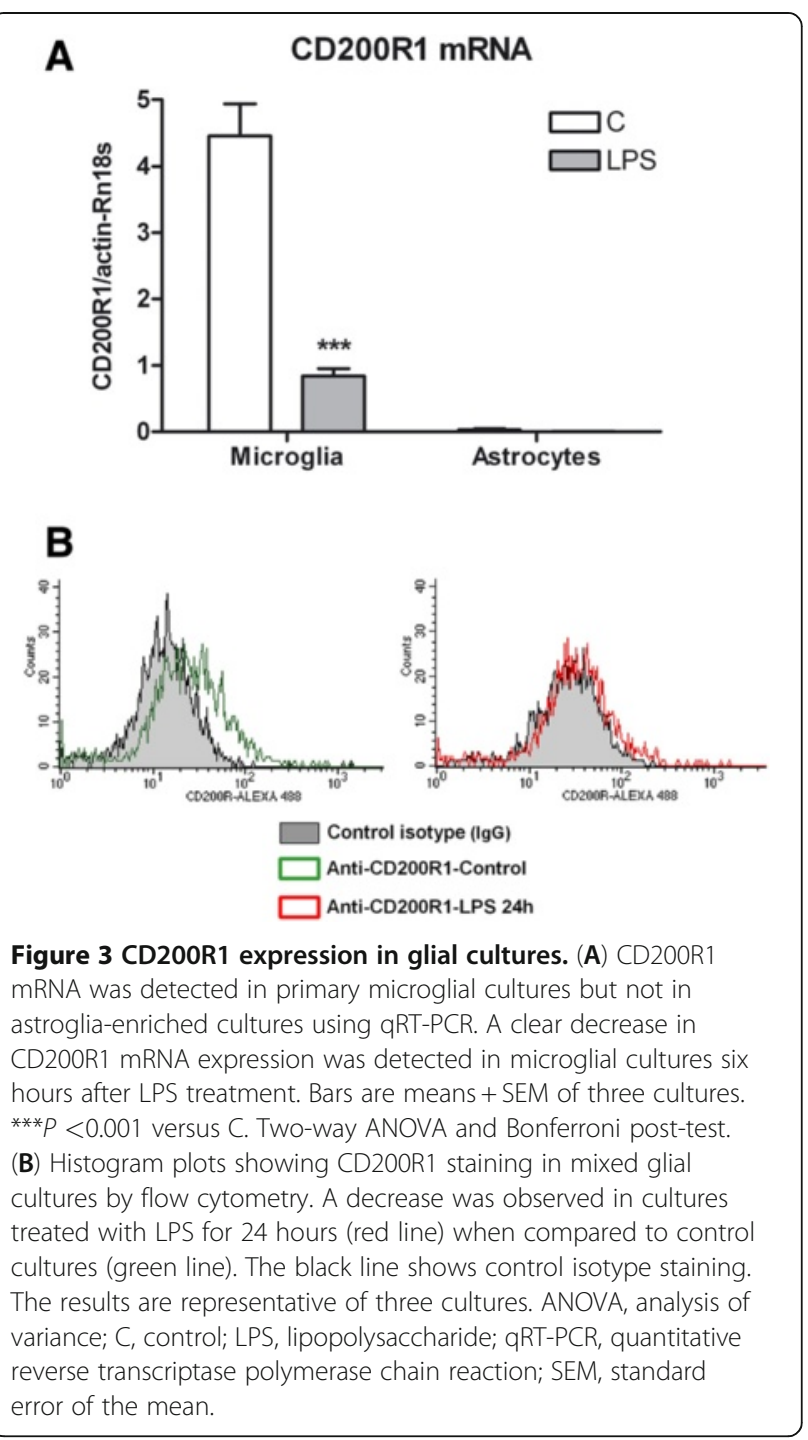

not observed in LPS-treated C/EBP $\beta$-deficient cultures. This effect occurred without any alteration in CD200R1 mRNA expression in basal conditions in the absence of $\mathrm{C} / \mathrm{EBP} \beta$.

\section{C/EBP $\beta$ overexpression inhibits CD200R1 expression}

In order to evaluate whether an increase in the expression of C/EBP $\beta$ was sufficient to inhibit CD200R1 gene transcription in microglial cells, we overexpressed $\mathrm{C} /$ EBP $\beta$ in BV2 cells. We first confirmed the expression of CD200R1 in BV2 cells, and a decrease in this expression after LPS treatment (Figure 5A). We then prepared stable clones of BV2 overexpressing the C/EBP $\beta$ LAP isoform (BV2-LAP cells), the most abundant $\mathrm{C} / \mathrm{EBP} \beta$ isoform in glial cells. C/EBP $\beta$ overexpression was tested using qRT-PCR and western blot, and significant increases in $\mathrm{C} / \mathrm{EBP} \beta \mathrm{mRNA}$ (Figure $5 \mathrm{~B}$ ) and $\mathrm{C} / \mathrm{EBP} \beta$ LAP protein (Figure $5 \mathrm{C}$ ) were observed in control BV2- 


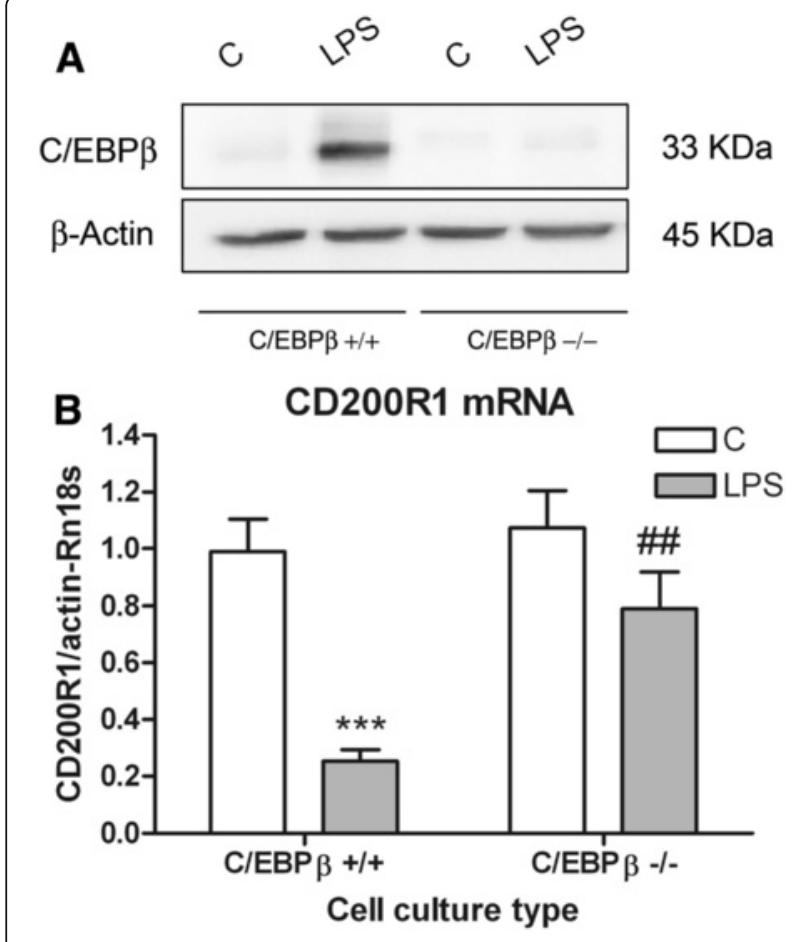

Figure 4 CD200R1 expression in the absence of C/EBP $\beta$.

(A) Western blot showing C/EBP $\beta$ protein expression in total protein extracts of primary mixed glial cultures from control and LPS-treated wild-type and C/EBPß-deficient mice.

(B) CD200R1 mRNA expression in primary mixed glial cultures from control and LPS-treated (six hours) wild-type and C/EBP $\beta$-deficient mice. The decrease in CD200R1 mRNA expression induced by LPS in wild-type cultures was not observed in C/EBP $\beta$-deficient cultures. Bars are means + SEM of three to four independent experiments. ${ }^{* * *} P<0.001$ versus $C_{;} \# \# P<0.01$ versus wild type LPS-treated cultures. Two-way ANOVA and Bonferroni post-test. ANOVA, analysis of variance; $C$, control; C/EBP $\beta$, CCAAT/enhancer binding protein $\beta$; LPS, lipopolysaccharide; SEM, standard error of the mean.

LAP cells in comparison to BV2-pCDNA clones (no LAP overexpression). LPS treatment increased C/EBP $\beta$ expression in both BV2-pCDNA and BV2-LAP cells.

C/EBP $\beta$ overexpression resulted in a significant decrease in CD200R1 mRNA in untreated BV2-LAP cells in comparison to untreated BV2-pCDNA cells (Figure 6A). LPS induced a significant decrease in CD200R1 mRNA in both types of clones. A decrease in CD200R1 protein was also observed in BV2-LAP cells versus BV2-pCDNA cells in untreated cultures via flow cytometry (Figure 6B-D). A significant decrease in both the number of cells expressing CD200R1 and the levels of CD200R1 expression was detected in control BV2-LAP cells versus BV2pCDNA cells.

C/EBP $\beta$ binds to the CD200R1 promoter in response to LPS We next studied whether the effect of $C / E B P \beta$ on CD200R1 regulation was due to a direct interaction with

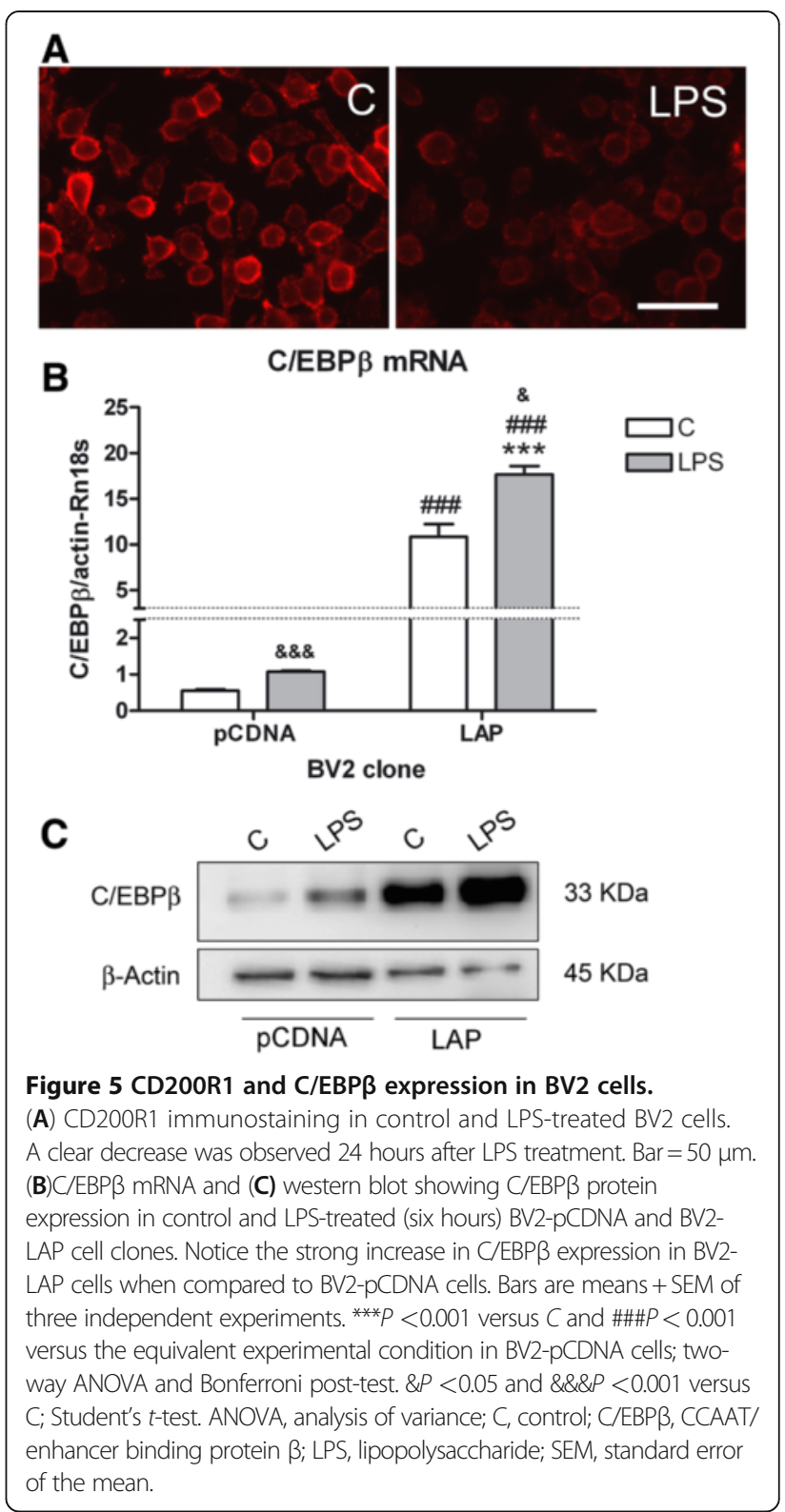

the gene promoter. We first analyzed the 5,000 bp region upstream from the translation start site of the CD200R1 gene using the bioinformatic softwares Match1.0 (public version, BioBase) and MatInspector (Genomatix), looking for putative C/EBP $\beta$ binding sites. Six putative binding sites (herein referred to as box 1 to 6 ) were identified, the positions and sequences of which are indicated in Table 1.We then investigated whether $\mathrm{C} / \mathrm{EBP} \beta$ could bind to these sites in a qChIP assay using primary mixed glial cultures. Due to their proximity to each other (less than 500 bp apart), it was impossible to distinguish binding to box 1 and 2 or to box 3 and 4 using our experimental approach. We did not detect any $\mathrm{C} / \mathrm{EBP} \beta$ binding to the CD200R1 gene promoter in untreated primary mixed glial cultures. However, 

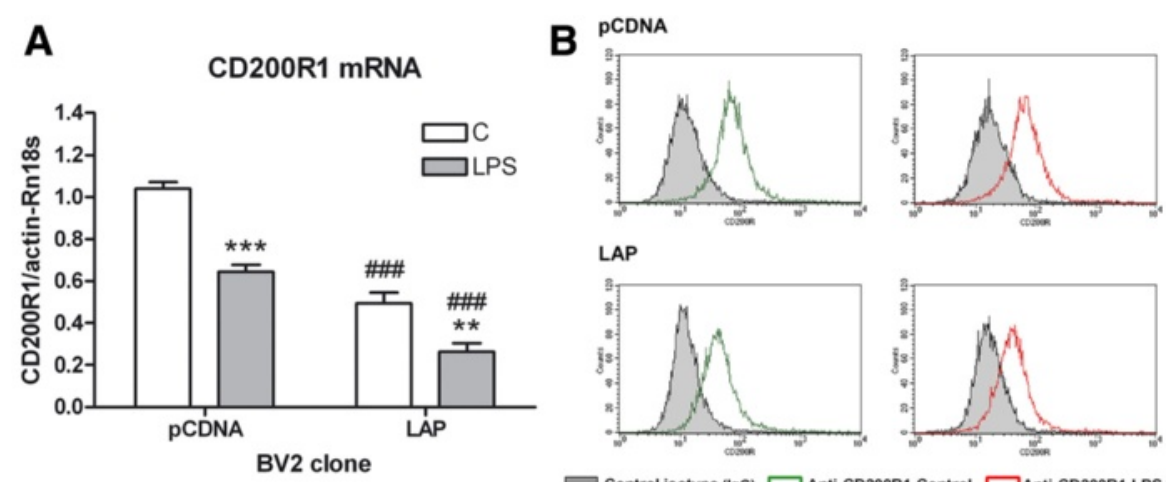

D
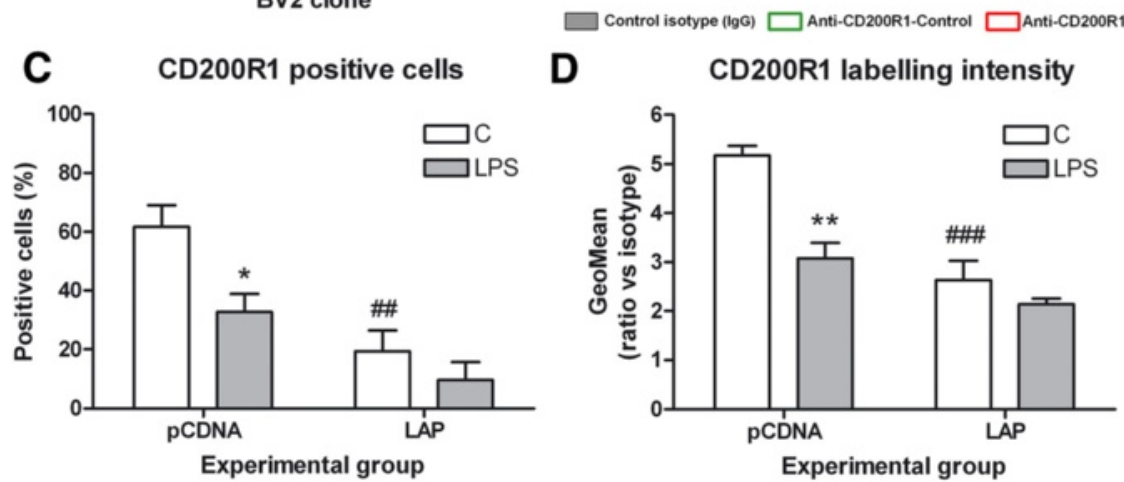

Figure 6 CD200R1 expression in BV2 cells: effect of C/EBP $\beta$ overexpression. (A) CD200R1 mRNA expression in control and LPS-treated (six hours) BV2-pCDNA and BV2-LAP cell clones. (B-D) CD200R1 protein in control and LPS-treated (24 hours) BV2-pCDNA and BV2-LAP cells according to flow cytometry. (B) Histogram plots, representative of three independent experiments, showing CD200R1 staining in the BV2 cell clones. (C) Quantification of CD200R1 positive cells and fluorescence intensity (D) in each experimental group. CD200R1 mRNA and protein expression was lower in BV2-LAP cells than in BV2-pCDNA cells, due to an increase in both the number of CD200R1 positive cells and the level of CD200R1 protein expression. Bars are means + SEM of three independent experiments. ${ }^{*} P<0.05,{ }^{* *} P<0.01$ and ${ }^{* * *} P<0.001$ versus $C$; \#\#P<0.01 and \#\#\#P<0.001 versus the equivalent experimental condition in BV2-pCDNA cells. Two-way ANOVA and Bonferroni post-test. ANOVA, analysis of variance; $C$, control; C/EBP $\beta$, CCAAT/enhancer binding protein $\beta$; LPS, lipopolysaccharide; SEM, standard error of the mean.

significant binding of C/EBP $\beta$ to the CD200R1 gene promoter was observed after LPS-treatment, but only at the binding site closest to the ATG translation start site (box 6) (Figure 7A).

Using our BV2 cell clones, we also assessed whether $\mathrm{C} / \mathrm{EBP} \beta$ overexpression resulted in increased binding of the transcription factor to the CD200R1 gene promoter. As in mixed glial cultures, significant $C / E B P \beta$ binding to the CD200R1 gene promoter in BV2-pCDNA cells was only detected after LPS treatment, at the binding site closest to the ATG translation start site (Figure 7B). Nevertheless, significant C/EBP $\beta$ binding at the same site was observed in untreated BV2-LAP cells. No differences in C/EBP $\beta$ binding were observed between control and LPS-treated BV2-LAP cells.

\section{C/EBP $\beta$ interacts with HDAC1 and determines the inhibition of CD200R1 expression in microglial cells}

To further elucidate the mechanism that underlies the C/EBP $\beta$-mediated inhibition of CD200R1 transcription in microglial cells, we analyzed the possible involvement of histone deacetylases. HDAC1 may mediate the effect of $C / E B P \beta$, given the role of this enzyme in histone modifications linked to gene expression inactivation. Using co-immunoprecipitation, we found that HDAC1 interacts with $C / E B P \beta$ mixed glial cultures treated with LPS for six hours (Figure 8A). We then analyzed whether HDAC1 was present in box 6 in the CD200R1 promoter using the qChIP assay. We detected binding of HDAC1 in LPS-treated mixed glial cultures (Figure 8B), suggesting that $\mathrm{HDAC} 1$ could interact with $\mathrm{C} / \mathrm{EBP} \beta$ to control CD200R1 transcription. Finally, we also investigated whether HDAC1 could play an active role in the transcription of CD200R1, using the HDAC inhibitors SAHA and MS-275. We observed that the inhibition of CD200R1 mRNA expression detected in mixed glial cultures after LPS treatment was partially reverted by both HDAC inhibitors (Figure 8B and C).

\section{Discussion}

The results demonstrate that $\mathrm{C} / \mathrm{EBP} \beta$ is critically involved in the regulation of CD200R1 gene expression in reactive microglial cells. CD200R1 expression decreases in microglia in response to the pro-inflammatory stimulus 


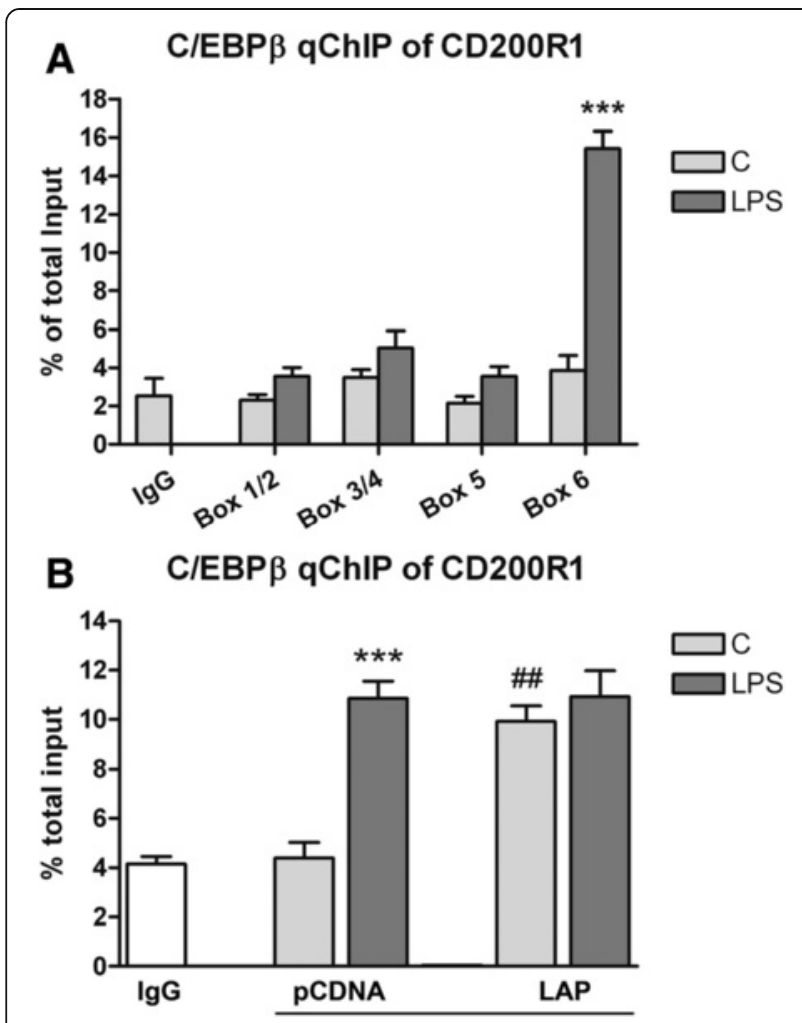

Figure 7 C/EBP $\beta$ binding to CD200R1 gene promoter in glial cells. (A) Analysis of C/EBP $\beta$ binding to six putative binding sites of the CD200R1 gene promoter in primary mixed glial cultures by qChIP. Significant binding of C/EBP $\beta$ was only observed in box 6 in LPS-treated cultures (four hours). Bars are means + SEM of three independent experiments. ${ }^{* *} P<0.001$ versus IgG and C. One-way ANOVA and Bonferroni post-test. (B) C/EBP $\beta$ binding to box 6 of the CD200R1 gene promoter in BV2 PCDNA and BV2-LAP cells. Significant binding of C/EBP $\beta$ was observed in LPS-treated (four hours) BV2-pCDNA cells but also in control BV2-LAP cells. LPS treatment did not induce a further increase in C/EBP $\beta$ binding in LPS-treated BV2-LAP cells. Bars are means + SEM of three independent experiments. ${ }^{* *} P<0.001$ versus IgG and $C_{;} \# \# P<0.01$ versus the equivalent experimental condition in BV2-pCDNA cells. Two-way ANOVA and Bonferroni post-test. ANOVA, analysis of variance; $C$, control; C/EBP $\beta$, CCAAT/enhancer binding protein $\beta$; IgG, immunoglobulin G; LPS, lipopolysaccharide; qChIP, quantitative chromatin immunoprecipitation; SEM, standard error of the mean.

LPS. However, this effect is not observed in the absence of $\mathrm{C} / \mathrm{EBP} \beta$ and, in contrast, C/EBP $\beta$ overexpression results in a decrease in CD200R1 expression in microglial cells in basal conditions. We also show that, in response to LPS, C/EBP $\beta$ binds the CD200R1 promoter and that C/EBP $\beta$ interacts with HDAC1. These observations suggest that the decrease in CD200R1 expression induced by LPS in microglial cells is due, at least in part, to C/EBP $\beta$ transcriptional regulation through a mechanism involving histone deacetylation.
In the CNS, it has been suggested that the CD200CD200R1 interaction is one of the cell-contact mechanisms involved in the regulation of microglial activity by neurons. Results from studies using CD200-deficient mice and experimental models of inflammatory diseases show that the CD200-CD200R1 interaction keeps microglial cells in a quiescent/surveying phenotype in which the pro-inflammatory response is inhibited, and that microglial cells show increased reactivity when the CD200-CD200R1 signal is impaired [6,8,25-28]. However, the mechanisms of inhibition of pro-inflammatory activity triggered by CD200-CD200R1 signaling in microglial cells have not been characterized. The signal transduction pathways responsible for the inhibitory effects of CD200R1 engagement have only been partially described in mouse mast cells overexpressing CD200R1 differentiated in vitro [29] and in the human lymphoma cell line U937 [30]. On the other hand, little is known about the molecular mechanisms regulating CD200 and CD200R1 expression in the CNS. We observed that microglial CD200R1 expression decreases in response to a pro-inflammatory stimulus. This effect would result in decreased interaction between CD200 and CD200R1 in the presence of neurons, which in turn would reduce the inhibitory input microglia receive from neurons in normal conditions. Consequently, one of the mechanisms contributing to the induction of a reactive microglia phenotype by proinflammatory factors may be the down-regulation of inhibitory pathways such as CD200-CD200R1 signaling.

Glial activation results in significant changes in the expression of a large number of genes, among them those encoding pro-inflammatory and anti-inflammatory molecules. The expression of these genes must be tightly regulated in order to orchestrate a controlled inflammatory response lasting no longer than necessary. Various transcription factors are involved in the regulation of this expression (NF-kB, AP-1, STATs, PPARs, C/EBPs), resulting in fine regulation of the inflammatory response from start to finish. The transcriptional regulation of CD200R1 has not been studied. We show here that C/ EBP $\beta$ is one of the transcription factors that is activated by pro-inflammatory stimuli playing a role in the regulation of CD200R1 transcription. C/EBP $\beta$ does not appear to play a role in the constitutive expression of CD200R1 in microglial cells, given that we did not detect any alteration in basal levels of CD200R1 mRNA expression in control $C / E B P \beta$-deficient glial cultures. Nevertheless, increased levels of C/EBP $\beta$ down-regulate CD200R1 expression, as observed in LPS-treated wildtype glial cultures and not in C/EBP $\beta$-deficient cultures, as well as in BV2 cells overexpressing C/EBP $\beta$. These results suggest that $C / E B P \beta$ upregulation in response to LPS contributes to the development of a 


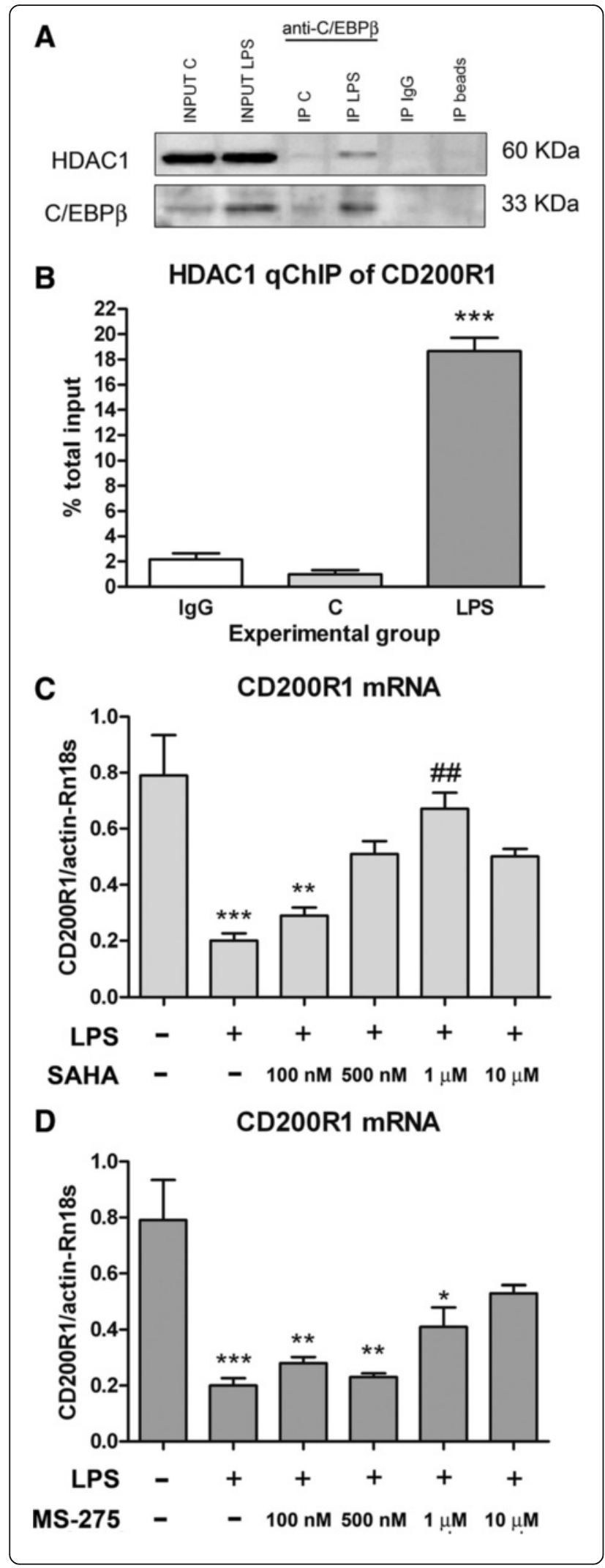

Figure 8 Involvement of HDAC1 in the inhibition of CD200R1 expression by C/EBP $\beta$. (A) Western blot showing HDAC1 (upper image) and C/EBP $\beta$ (lower image) expression in nuclear protein extracts from primary mixed glial cultures before (Input) and after immunoprecipitation (IP) with anti-C/EBP $\beta$ antibody. HDAC1-C/EBP $\beta$ co-immunoprecipitation was observed in LPS-treated cultures. Samples immunoprecipitated with isotype or unlabeled beads were used as controls to demonstrate the specificity of the signal obtained. (B) Analysis of HDAC1 binding to C/EBP $\beta$ box 6 of CD200R1 gene promoter by qChIP, showing interaction between HDAC1 and C/EBP $\beta$ in LPS-treated cultures. Bars are means + SEM of three independent experiments. ${ }^{* *} P<0.001$ versus $\lg G$ and $C$. One-way ANOVA and Bonferroni post-test. Effect of the HDAC inhibitors SAHA (C) and MS-275 (D) on CD200R1 mRNA expression in control and LPS-treated primary mixed glial cultures. Both attenuated LPS-induced inhibition of CD200R1 expression. Bars are means + SEM of three independent experiments. ${ }^{*} P<0.05$, ${ }^{* *} P<0.01$ and ${ }^{* *} P<0.001$ versus $C$; \#\#P $<0.01$ versus LPS. One-way ANOVA and Bonferroni post-test. ANOVA, analysis of variance; $C$, control; C/EBP $\beta$, CCAAT/enhancer binding protein $\beta ; \mathrm{HDAC1}$, histone deacetylase 1; IgG, immunoglobulin G; LPS, lipopolysaccharide; qChIP, quantitative chromatin immunoprecipitation; SAHA, suberoylanilide hydroxamic acid; SEM, standard error of the mean.

pro-inflammatory phenotype in microglial cells through the inhibition of CD200R1 transcription.

In recent years, we have been studying the involvement of C/EBP $\beta$ in glial activation. Using in vitro and in vivo experimental approaches we have reported the expression of $C / E B P \beta$ in astroglial and microglial cells, and an increase in $C / E B P \beta$ expression in reactive glial cells in response to pro-inflammatory stimuli and neuronal death [18,31-33]. This increase was further accentuated in reactive microglial cells of G93A-SOD1 mice (animal model of amyotrophic lateral sclerosis) and also observed in microglial cells in the spinal cord of amyotrophic lateral sclerosis patients [32]. All these results suggest an active role for $\mathrm{C} / \mathrm{EBP} \beta$ in glial activation. $\mathrm{C} /$ EBP binding sites have been found in the promoters of many genes encoding pro-inflammatory molecules [3436]. C/EBP $\beta$ regulates the LPS and LPS/IFN $\gamma$-induced transcription of IL-6, IL-1 $\beta$, TNF- $\alpha$, COX-2 and iNOS genes [18,37-41]. Interestingly, C/EBP $\beta$ deficiency has a neuroprotective effect following ischemic [42] and excitotoxic injuries [17], as well as in an in vitro model of neuroinflammation [18]. Nevertheless, little is known about the involvement of $\mathrm{C} / \mathrm{EBP} \beta$ in the transcriptional regulation of genes encoding anti-inflammatory molecules, and even less so in CNS cells. Some authors have reported a role for $\mathrm{C} / \mathrm{EBP} \beta$ in induction of the expression of the anti-inflammatory cytokine IL-10 in response to LPS $[43,44]$ or other stimuli $[45,46]$ in macrophages. These observations, together with the results of the present study, suggest that, apart from its role in the expression of pro-inflammatory molecules, $\mathrm{C} / \mathrm{EBP} \beta$ plays a role in the control of the expression of anti-inflammatory molecules, either activating or inhibiting their expression. This 
constitutes an additional point of regulation of the inflammatory response in glial cells by $C / E B P \beta$.

Several mechanisms may be responsible for the inhibition of CD200R1 gene transcription by C/EBP $\beta$. In vitro studies using different cell types have shown that the transactivating activity of $\mathrm{C} / \mathrm{EBP} \beta$ in the transcription of target genes can be inhibited by post-translational modifications such as sumoylation [47,48], phosphorylation $[49,50]$, methylation [51], deacetylation [52,53] and glycosylation [54]. Interestingly, $\mathrm{C} / \mathrm{EBP} \beta$ has been shown to associate with co-repressor complexes containing HDACs in a gene promoter and inhibit gene transcription [55-57]. The acetylation status of histones is a key determinant of transcriptional activity (reviewed in [58]). Histone acetyltransferases and HDACs are the enzymes that reversibly catalyze histone acetylation. Recruitment of histone acetyltransferases to gene promoters is usually associated with the facilitation of gene transcription, while that of HDACs is associated with gene repression. However, it has been shown that a dynamic equilibrium between acetylation and deacetylation is also necessary for transcriptional activity. Using glial cultures, we found that $\mathrm{C} / \mathrm{EBP} \beta$ interacts with HDAC1 and that HDAC1 binds the CD200R1 promoter at a C/EBP $\beta$ consensus sequence following LPS treatment. These results, together with the observation that HDAC inhibitors reverse the LPS-induced reduction in CD200R1 expression, suggest that HDAC1 plays a role in the C/EBP $\beta$-mediated repression of CD200R1 transcription observed in microglial cells in response to LPS treatment. However, the possible involvement of other HDACs cannot be ruled out. This mechanism of transcriptional repression could involve both histone deacetylation [55-57], resulting in changes in chromatin structure and consequently in transcriptional activity, and $C / E B P \beta$ deacetylation [52,53], resulting in direct changes in transcriptional activity.

In recent years, several in vitro studies have shown that HDAC inhibitors down-regulate pro-inflammatory gene expression in macrophages and glial cells [59], as well as in other cell types [60-62], in response to inflammatory stimuli. HDAC inhibitors also attenuate the pro-inflammatory response in experimental models of cerebral ischemia [63] and endotoxemia in vivo [61]. Our results suggest that the anti-inflammatory effects of HDAC inhibitors can be mediated, at least in part, by potentiating the transcription of genes involved in keeping the pro-inflammatory response under control, such as CD200R1.

\section{Conclusions}

We describe, for the first time, a molecular mechanism involved in the regulation of the expression of CD200R1 in microglial cells, in which the transcription factor $\mathrm{C} / \mathrm{EBP} \beta$ plays a role. CD200R1 expression decreases in microglial cells in response to a pro-inflammatory stimulus, reducing the input that inhibits the microglial proinflammatory phenotype in physiological conditions. We show that $C / E B P \beta$, in addition to its known role in the regulation of the expression of pro-inflammatory genes, can also negatively regulate the expression of genes involved in the inhibition of the pro-inflammatory response, such as CD200R1, thus contributing to the development of the pro-inflammatory phenotype in microglial cells. HDAC1 may mediate the inhibition of CD200R1 expression by C/EBP $\beta$ through changes in chromatin structure and transcriptional activity.

\section{Abbreviations}

ANOVA: analysis of variance; bp: base pair; BSA: bovine serum albumin; C/EBPB: CCAAT/enhancer binding protein $\beta$; CNS: central nervous system; Ct: cycle threshold; DIV: days in vitro; DMEM: Dulbecco's modified Eagle's medium; DTT: dithiothreitol; EAE: experimental autoimmune encephalomyelitis; FBS: fetal bovine serum; HDAC: histone deacetylase; IFNY: interferon $\gamma$; IgG: immunoglobulin G; IL: interleukin;

LPS: lipopolysaccharide; PBS: phosphate buffered saline; PCR: polymerase chain reaction; PVDF: polyvinylidene fluoride; qChIP: quantitative chromatin immunoprecipitation; qRT-PCR: quantitative reverse transcriptase-polymerase chain reaction; RIPA: radioimmunoprecipitation assay; SAHA: suberoylanilide hydroxamic acid; SEM: standard error of the mean; TBS: tris-buffered saline; TNF: tumor necrosis factor.

\section{Competing interests}

The authors declare that they have no competing interests.

\section{Acknowledgements}

We thank Colleen Croniger and Valeria Poli for the generous gift of C/EBP $\beta$ knockout mice, Teresa Domingo and colleagues at the animal facilities of the School of Pharmacy(University of Barcelona) for their professional care of the C/EBP $\beta$ knockout mice, Steven Smale for providing PCDNA and pCDNA-LAP expression plasmids, Isabel Crespo and Cristina López from the Cytomics Platform of IDIBAPS for their technical assistance in the flow cytometry experiments, and Peter Podlesniy and Joana Figueiro-Silva for advice in Co-IP experiments. GD and MS are recipients of contracts from IDIBAPS and JAECSIC, respectively. This study was supported by grants PI081396 and PI10/ 378 of the Instituto de Salud Carlos III, Spain, and La Marató de TV3 foundation.

\section{Author details}

'Department of Cerebral Ischemia and Neurodegeneration, Institut $d^{\prime}$ Investigacions Biomèdiques de Barcelona-Consejo Superior de Investigaciones Científicas (CSIC), Institut d'Investigacions Biomèdiques August Pi i Sunyer (IDIBAPS), C/ Rosselló 161, 6th Floor, Barcelona E-08036, Spain. ${ }^{2}$ Biochemistry and Molecular Biology Unit, School of Medicine, University of Barcelona IDIBAPS, Barcelona, Spain.

\section{Authors' contributions}

GD performed most of the experiments, analyzed the data and helped write the manuscript. MS obtained and treated the mixed glial cultures in the experiments with C/EBP $\beta$-deficient mice. AEO obtained the PCDNA-BV2 and LAP-BV2 cell clones. JMT and JSe participated in immunocytochemistry experiments. JSa provided critical guidance and contributed to the final version of the manuscript. CS conceived and coordinated the study, provided guidance in the production of data and drafted the manuscript. All authors critically revised and approved the final manuscript.

Received: 9 March 2012 Accepted: 9 July 2012

Published: 9 July 2012

\section{References}

1. Hanish UK, Kettenmann H: Microglia: active sensor and versatile effector cells in the normal and pathologic brain. Nat Neurosci 2007, 10:1387-1394. 
2. Ransohoff RM, Perry VH: Microglial physiology: unique stimuli, specialized responses. Annu Rev Immunol 2009, 27:119-145.

3. Gao H-M, Hong J-S: Why neurodegenerative diseases are progressive: uncontrolled inflammation drives disease progression. Trends Immunol 2008, 29:357-365.

4. Ransohoff RM, Cardona AE: The myeloid cells of the central nervous system parenchyma. Nature 2010, 468:253-262.

5. Boudakov I, Liu J, Fan N, Gulay P, Wong K, Gorczynski RM: Mice lacking CD200R1 show absence of suppression of lipopolysaccharide-induced tumor necrosis factor-a and mixed leukocyte culture responses by CD200. Transplantation 2007, 84:251-257.

6. Broderick C, Hoek RM, Forrester JV, Liversidge J, Sedgwick JD, Dick AD: Constitutive retinal CD200 expression regulates resident microglia and activation state of inflammatory cells during experimental autoimmune uveoretinitis. Amm J Pathol 2002, 161:1669-1677.

7. Copland DA, Calder CJ, Raveney BJ, Nicholson LB, Phillips J, Cherwinski H, Jenmalm M, Sedgwick JD, Dick AD: Monoclonal antibody-mediated CD200 receptor signalling supresses macrophage activation and tissue damage in experimental autoimmune uveoretinitis. Am J Pathol 2007 171:396-398.

8. Hoek RM, Ruuls SR, Murphy CA, Wright GJ, Goddard R, Zurawski SM Blom B, Homola ME, Streit WJ, Brown MH, Barclay AN, Sedgwick JD: Down-regulation of the macrophage lineage through interaction with OX2 (CD200). Science 2000, 290:1768-1771.

9. Lyons A, Downer EJ, Crotty S, Nolan YM, Mills KH, Lynch MA: CD200 ligand-receptor interaction modulates microglial activation in vivo and in vitro: a role for IL-4. J Neurosci 2007, 27:8309-8313.

10. Lyons A, McQuillan A, Deighan BF, O'Reilly J-A, Downer EJ, Murphy AC, Watson M, Piazza A, O'Connell F, Griffin R, Mills KHG, Lynch MA: Decreased neuronal CD200 expression in IL-4-deficient mice results in increased neuroinflammation in response to lipopolysaccharide. Brain Behav Immun 2009, 23:1020-1027.

11. Koning N, Bö L, Hoek RM, Huitinga l: Downregulation of macrophage inhibitory molecules in multiple sclerosis lesions. Ann Neurol 2007, 62:504-514

12. Koning N, Swaab DF, Hoek RM, Huitinga I: Distribution of the immune inhibitory molecules CD200 and CD200R in the normal central nervous system and multiple sclerosis lesions suggests neuron-glia and glia-glia interactions. J Neuropathol Exp Neurol 2009, 68:159-167.

13. Walker DG, Dalsing-Hernandez JE, Campbell NA, Lue L-F: Decreased expression of CD200 and CD200 receptor in Alzheimer's disease: a potential mechanism leading to chronic inflammation. Exp Neurol 2009, 215:5-19.

14. Rosenblum MD, Olasz E, Woodliff JE, Johnson BD, Konkol MC, Gerber KA, Orentas RJ, Sandford G, Truitt RL: CD200 is a novel p53-target gene involved in apoptosis-associated immune tolerance. Blood 2008, 103:2691-2698.

15. Chen Z, Marsden PA, Gorczynski RM: Cloning and characterization of the human CD200 promoter region. Mol Immunol 2006, 43:579-587.

16. Chen Z, Marsden PA, Gorczynski RM: Role of a distal enhancer in the transcriptional responsiveness of the human CD200 gene to interferon- $\gamma$ and tumor necrosis factor-a. Mol Immunol 2009, 46:1951-1963.

17. Cortes-Canteli M, Luna-Medina R, Sanz-Sancristobal M, Alvarez-Barrientos A, Santos A, Perez-Castillo A: CCAAT/enhancer binding protein beta deficiency provides cerebral protection following excitotoxic injury. J Cell Sci 2008, 121:1224-1234

18. Straccia M, Gresa-Arribas N, Dentesano G, Ejarque-Ortiz A, Tusell JM, Serratosa J, Solà C, Saura J: Pro-inflammatory gene expression and neurotoxic effects of activated microglia are attenuated by absence of CCAAT/enhancer binding protein beta. J Neuroinflam 2011, 8:156-170.

19. Screpanti I, Romani L, Musiani P, Modesti A, Fattori E, Lazzaro D, Sellitto C, Scarpa S, Bellavia D, Lattanzio G, et al: Lymphoproliferative disorder and imbalanced T-helper response in C/EBP beta-deficient mice. EMBO J 1995, 14:1932-1941.

20. Gresa-Arribas N, Serratosa J, Saura J, Solà C: Inhibition of CCAAT/enhancer binding protein $\delta$ expression by chrysin in microglial cells results in anti-inflammatory and neuroprotective effects. J Neurochem 2010, 115:526-536.

21. Saura J, Tusell JM, Serratosa J: High-yield isolation of murine microglia by mild trypsinization. Glia 2003, 44:183-189.

22. Saura J, Angulo E, Ejarque A, Casado V, Tusell JM, Moratalla R, Chen J-F, Schwarzschild MA, Lluis C, Franco R, Serratosa J: Adenosine A2A receptor stimulation potentiates nitric oxide release by activated microglia. J Neurochem 2005, 95:919-929.

23. Blasi E, Barluzzi R, Bocchini V, Mazzolla R, Bistoni F: Immortalization of murine microglial cells by a v-raf/v-myc carrying retrovirus. J Neuroimmunol 1990, 27:229-237.

24. Livak KJ, Schmittgen TD: Analysis of relative gene expression data using real-time quantitative PCR and the 2(-Delta Delta C(T)). Methods 2001 25:402-408.

25. Wright GJ, Puklavec MJ, Willis AC, Hoek RM, Sedgwick JD, Brown MH, Barclay AM: Lymphoid/neuronal cell surface glycoprotein recognizes a novel receptor on macrophages implicated in the control of their function. Immunity 2000, 13:233-242.

26. Meuth SG, Simon OJ, Grimm A, Melzer N, Herrmann AM, Spitzer P, Landgraf $P$, Wiendl H: CNS inflammation and neuronal degeneration is aggravated by impaired CD200-CD200R-mediated macrophage silencing. J Neuroimmunol 2008, 194:62-69.

27. Liu Y, Bando Y, Vargas-Lowy D, Elyaman W, Khoury SJ, Huang T, Reif K, Chitnis T: CD200R1 agonist attenuates mechanisms of chronic disease in a murine model of multiple sclerosis. J Neurosci 2010, 30:2025-2038.

28. Chitnis T, Imitola J, Wang Y, Elyaman W, Chawla P, Sharuk M, Raddassi K, Bronson RT, Koury SJ: Elevated neuronal expression of CD200 protects $W I d^{5}$ mice from inflammation-mediated neurodegeneration. Am J Pathol 2007, 170:1695-1712.

29. Zhang S, Cherwinski H, Sedgwick JD, Phillips JH: Molecular mechanisms of CD200 inhibition of mast cell activation. J Immunol 2004, 173:6786-6793.

30. Mihrshahi R, Barclay AN, Brown MH: Essential roles for Dok2 and RasGAP in CD200 receptor-mediated regulation of human myeloid cells. $\mathrm{J}$ Immunol 2009, 183:4879-4886.

31. Ejarque-Ortiz A, Medina MG, Tusell JM, Pérez-González AP, Serratosa J, Saura $\mathrm{J}$ : Upregulation of CCAAT/enhancer binding protein $\beta$ in activated astrocytes and microglia. Glia 2007, 55:178-188.

32. Valente T, Mancera P, Tusell JM, Serratosa J, Saura J: C/EBP $\beta$ expression in activated microglia in amyotrophic lateral sclerosis. Neurobiol Aging in press.

33. Pérez-Capote K, Saura J, Serratosa J, Solà C: Expression of C/EBPalpha and $\mathrm{C} / \mathrm{EBPbeta}$ in glial cells in vitro after inducing glial activation by different stimuli. Neuroscience Lett 2006, 410:25-30.

34. Lowenstein CJ, Alley EW, Raval P, Snowman AM, Snyder SH, Russell SW, Murphy WJ: Macrophage nitric oxide synthase gene: two upstream regions mediate induction by interferon gamma and lipopolysaccharide. Proc Natl Acad Sci U S A 1993, 90:9730-9734.

35. Wadleigh DJ, Reddy ST, Kopp E, Ghosh S, Herschman HR: Transcriptional activation of the cyclooxygenase- 2 gene in endotoxin-treated RAW 264.7 macrophages. J Biol Chem 2000, 275:6259-6266.

36. Caivano M, Gorgoni B, Cohen P, Poli V: The induction of cyclooxygenase-2 mRNA in macrophages is biphasic and requires both CCAAT enhancerbinding protein beta (C/EBP beta) and C/EBP delta transcription factors. J Biol Chem 2001, 276:48693-48701.

37. Matsusaka T, Fujikawa K, Nishio Y, Mukaida N, Matsushima K, Kishimoto T, Akira S: Transcription factors NF-IL6 and NF-kappa B synergistically activate transcription of the inflammatory cytokines, interleukin 6 and interleukin 8. Proc Natl Acad Sci U S A 1993, 90:10193-10197.

38. Liu H, Sidiropoulos P, Song G, Pagliari LJ, Birrer MJ, Stein B, Anrather J, Pope RM: TNF-alpha gene expression in macrophages: regulation by NF-kappa B is independent of c-Jun or C/EBP beta. J Immunol 2000, 164:4277-4285.

39. Gorgoni B, Maritano D, Marthyn P, Righi M, Poli V: C/EBP beta gene inactivation causes both impaired and enhanced gene expression and inverse regulation of IL-12 p40 and p35 mRNAs in macrophages. J Immunol 2002, 168:4055-4062.

40. Chen J, Ivashkiv LB: IFN- $\gamma$ abrogates endotoxin tolerance by facilitating toll-like receptor-induced chromatin remodeling. Proc Natl Acad Sci U S A 2010, 107:19438-19443.

41. Yan C, Cao J, Wu M, Zhang W, Jiang T, Yoshimura A, Gao H: Suppressor of cytokine signaling 3 inhibits LPS-induced IL-6 expression in osteoblasts by suppressing CCAAT/enhancer-binding protein beta activity. J Biol Chem 2010, 285:37227-37239.

42. Kapadia R, Tureyen K, Bowen KK, Kalluri H, Johnson PF, Vemuganti R: Decreased brain damage and curtailed inflammation in transcription factor CCAAT/enhancer binding protein beta knockout mice following transient focal cerebral ischemia. J Neurochem 2006, 98:1718-1731. 
43. Liu YW, Tseng HP, Chen LC, Chen BK, Chang WC: Functional cooperation of simian virus 40 promoter factor 1 and CCAAT/enhancer-binding protein beta and delta in lipopolysaccharide-induced gene activation of IL-10 in mouse macrophages. J Immunol 2003, 171:821-828.

44. Liu YW, Chen CC, Tseng HP, Chang WC: Lipopolysaccharide-induced transcriptional activation of interleukin-10 is mediated by MAPK- and NF-kappaB-induced CCAAT/enhancer-binding protein delta in mouse macrophages. Cell Signal 2006, 18:1492-1500.

45. Brenner S, Prösch S, Schenke-Layland K, Riese U, Gausmann U, Platzer C: CAMP-induced interleukin-10 promoter activation depends on CCAAT/ enhancer-binding protein expression and monocytic differentiation. J Biol Chem 2003, 278:5597-5604.

46. Csóka B, Németh ZH, Virág L, Gergely P, Leibovich SJ, Pacher P, Sun CX, Blackburn MR, Vizi ES, Deitch EA, Haskó G: A2A adenosine receptors and $\mathrm{C} / \mathrm{EBPb}$ ta are crucially required for IL-10 production by macrophages exposed to Escherichia coli. Blood 2007, 110:2685-2695.

47. Eaton EM, Sealy L: Modification of CCAAT/enhancer-binding protein-beta by the small ubiquitin-like modifier (SUMO) family members, SUMO-2 and SUMO-3. J Biol Chem 2003, 278:33416-33421.

48. Wang W-L, Lee Y-Ch, Yang W-M, Chang W-M, Chang W-Ch, Wang J-M: Sumoylation of LAP1 is involved in the HDAC4-mediated repression of COX-2 transcription. Nucleic Acid Res 2008, 36:6066-6079.

49. Ghosh AK, Bhattacharyya S, Mori Y, Varga J: Inhibition of collagen gene expression by interferon-gamma: novel role of the CCAAT/ enhancer binding protein beta (C/EBPbeta). J Cell Physiol 2006, 207:251-260.

50. Dong $L-Y$, Sun $G$, Jiang $L$, Shao $L$, Hu $Y$, Jiang $Y$, Wang $Y$, An $W$ : Epidermal growth factor down-regulates the expression of human hepatic stimulator substance via CCAAT/enhancer-binding protein $\beta$ in HepG2 cells. Biochem J 2010, 431:277-287.

51. Pless O, Kowenz-Leutz E, Knoblich M, Lausen J, Beyermann M, Walsch MJ, Leutz A: G9a-mediated lysine methylation alters the function of CCAAT/ enhancer-binding protein-beta. J Biol Chem 2008, 283:26357-26363.

52. Ceseña TI, Cui TX, Subramanian L, Fulton CT, Iñiguez-Lluhí JA, Kwok RPS, Schwartz J: Acetylation and deacetylation regulate CCAAT/enhancer binding protein $\beta$ at $\mathrm{K} 39$ in mediating gene transcription. Mol Cell Endocrinol 2008, 289:94-101.

53. Xu M, Nie L, Kim SH, Sun XH: STAT5-induced Id-1 transcription involves recruitment of HDAC1 and deacetylation of C/EBPbeta. EMBO J 2003, 22:893-904.

54. Li X, Molina H, Huang H, Zhang YY, Liu M, Qian SW, Slawson C, Dias WB, Pandey A, Hart GW, Lane MD, Tang QQ: O-linked N-acetylflucosamine modification on CCAAT enhancer-binding protein beta: role during adipocyte differentiation. J Biol Chem 2009, 284:19248-19254.

55. Di-Poï N, Desvergne B, Michalik L, Wahli W: Transcriptional repression of peroxisome proliferator-activated receptor $\beta / \delta$ in murine keratinocytes by CCAAT/enhancer-binding proteins. J Biol Chem 2005, 280:38700-38710.

56. Wiper-Bergeron N, Wu D, Pope L, Schild-Poulter C, Haché RJ: Stimulation of preadipocyte differentiation by steroid through targeting of an HDAC1 complex. EMBO J 2003, 22:2135-2145

57. Zuo Y, Qiang L, Farmer SR: Activation of CCAAT/enhancer-binding protein (C/EBP) expression by $C / E B P \beta$ during adipogenesis requires a peroxisome proliferators-activated receptor- $\gamma$-associated repression of HDAC1 at the C/ebpa gene promoter. J Biol Chem 2006, 281:7960-7967.

58. Shahbazian MD, Grunstein M: Functions of site-specific histone acetylation and deacetylation. Annu Rev Biochem 2007, 76:75-100.

59. Faraco G, Pittelli M, Cavone L, Fossati S, Porcu M, Mascagni P, Fossati G, Moroni F, Chiarugi A: Histone deacetylase (HDAC) inhibitors reduce the glial inflammatory response in vitro and in vivo. Neurobiol Dis 2009, 36:269-279.

60. Bode KA, Schroder K, Hume DA, Ravasi T, Heeg K, Sweet MJ, Dalpke AH: Histone deacetylase inhibitors decrease toll-like receptor-mediated activation of proinflammatory gene expression by impairing transcription factor recruitment. Immunology 2007, 122:596-606.

61. Choi Y, Park SK, Kim HM, Kang JS, Yoon YD, Han SB, Han JW, Yang JS, Han $\mathrm{G}$ : Histone deacetylase inhibitor $\mathrm{KBH}-\mathrm{A} 42$ inhibits cytokine production in RAW 264.7 macrophage cells and in in vivo endotoxemia model. Exp Mol Med 2008, 40:574-581.

62. Leoni F, Fossati G, Lewis EC, Lee JK, Porro G, Pagani P, Modena D, Moras ML, Pozzi P, Reznikov LL, Siegnund B, Fantuzzi G, Dinarello CA, Mascagni P.
The histone deacetylase inhibitor ITF2357 reduces production of pro-inflammatory cytokines in vitro and systemic inflammation in vivo. Mol Med 2005, 11:1-15.

63. Kim HJ, Rowe M, Ren M, Hong JS, Chen PS, Chiang DM: Histone deacetylase inhibitors exhibit anti-inflammatory and neuroprotective effects in a rat permanent ischemic model of stroke: multiple mechanisms of action. J Pharmacol Exp Ther 2007, 321:892-901.

doi:10.1186/1742-2094-9-165

Cite this article as: Dentesano et al:: Inhibition of CD200R1 expression by C/EBP beta in reactive microglial cells. Journal of Neuroinflammation 2012 9:165

\section{Submit your next manuscript to BioMed Central and take full advantage of:}

- Convenient online submission

- Thorough peer review

- No space constraints or color figure charges

- Immediate publication on acceptance

- Inclusion in PubMed, CAS, Scopus and Google Scholar

- Research which is freely available for redistribution
Ciomed Central 